\title{
The Effectiveness of Research-Based Learning Model in Educational Psychology Learning in Faculty of Education and Teachers Training Universitas Tidar
}

\author{
Sri Haryati ${ }^{1}$, Desi Nurhikmahyanti ${ }^{2}$, and Fifit Firmadani ${ }^{3}$ \\ \{sriharyati@untidar.ac.id $\left.{ }^{1}\right\}$ \\ ${ }^{1,2,3}$ Faculty of Education and Teachers Training, Universitas Tidar, Indonesia
}

\begin{abstract}
This research was aimed to test the effectiveness of the research-based learning model. This research was conducted in English Education Study Program, Indonesian Language and Literature Education Study Program and Science Education Study Program for second-semester students for each study program. The research method-used was Research and Development (R\&D), which consists of three steps, namely: the preparatory stage, the development stage, and the results reporting stage, which uses one group pre-test post-test design to analyze the data. Based on this research, the learning results show that: (1) there were significant differences of the learning result between before and after the treatment in using the research-based learning model, which were proven by the means score 56 to 85 , (2) the students' responses to the application of the research-based educational psychology textbook in the learning process for the three study programs state effectively and well-proven by getting students' responses of $76.84 \%$, and (3) there were no significant differences between three sample groups which use research-based learning model in learning, proven by t-test $<\mathrm{t}$-table.
\end{abstract}

Keywords: educational psychology textbook, research-based learning

\section{Introduction}

Research-based Learning (RBL) is an educational paradigm that is developed nowadays. The educational paradigm that continues is no longer teacher-centered but has been centered on learners (student-centered). The development of the 2013 Curriculum for secondary education and the KKNI Curriculum for higher education emphasizes learners to be able to think critically and independently in facing the demands of the development of science, technology, and art, or times changing. Related to this, the 2013 Curriculum mandates the existence of scientific learning, such as inquiry learning, discussion, problem-based learning, project-based learning, and cooperative learning [1].

In implementing the KKNI Curriculum, the minimum level of learning achievement is formulated as follows: (1) able to apply logical, critical, systematic, and innovative thinking in the context of the development or implementation of science and technology that pays attention to and applies the value of the humanities in accordance with the field of expertise based on rules, procedures, and scientific ethics in order to produce solutions, ideas, designs or art criticism; (2) able to compile a scientific description of the results of the study. The implementation in the learning process is by the standard process consisting of interactive, holistic, integrative, scientific, contextual, thematic, effective, collaborative, and studentcentered nature [2].

The National Education Standards Agency [3], which is contained in the 21st Century National Education paradigm, proposes a paradigm of education that is democratic, nuanced in a game, full of openness, challenging, giving practices of a responsibility sense, will stimulate 
students to come because they are happy not because of compulsion [4]. According to the $21^{\text {st }}$ Century Partnership Learning Framework in BNSP [3] and Hanib [4], there are several competencies that must be mastered by the human resources of the 21 st century, namely (1) critical thinking and problem-solving skill; (2) communication and collaboration skills; (3) creativity and innovation skills; (4) information and communication skills; (5) contextual learning skills, (6) information and literacy media skills. These competencies are expected to be owned by learners in following the learning process. Therefore, educators must be able to design and develop learner-centered learning and encourage learners to have 21st-century competencies or skills. The role of educators is significant as a facilitator and motivator.

The demands of competence that learners must have in 21 st-century learning contradict the real conditions of learning that occur today. In reality, there are still educators who do not facilitate learners to think critically in the learning process optimally. Educators have not used a variety of learning models that include: a variety of methods, a variety of media, a variety of approaches, and a variety of aids so that learning is not monotonous that makes students get bored quickly in attending the learning process. Learning is also still teacher-centered; such learning is still not supporting research-based learning. [5] suggests the characteristics of learning that can improve critical thinking skills are learning that involves active learners. Critical thinking is not easy to do, but critical thinking skills can be trained and developed by educators during the learning process. Therefore, educators need to apply a learning model that involves active learners and make them able to think critically. This condition is in line with the opinion of Snyder [5] that critical thinking skills must be developed, trained, and continuously integrated into the curriculum to stimulate active learners in the learning process. Learning models that can be developed by 2013 Curriculum principles, KKNI Curriculum, Researchbased Learning, 21st Century Learning includes problem-based learning, cooperative learning, contextual learning, inquiry learning, discourse learning, and project-based learning. Therefore, this paper discusses the learning models mentioned above and also the application in the Educational Psychology Learning subject.

\section{Research-Based Learning Models}

\subsection{Learning Models}

The learning model is part of a learning structure that has a broad scope, which includes approaches, strategies, methods, and learning techniques. A critical aspect of a learning model is syntax as the standard steps that must be taken in implementing the model. The language should be reflected in the learning steps, which is stated in the core learning activities in detail explanation. In developing a Lesson Planning or a Lecture Program Unit that applies a particular learning model, educator activities should reflect the syntax of the chosen learning model, as well as learning activities, should indicate how the behavior and interaction models are required.

There are several research-based learning models as the application of active learning methods in higher education, namely:

\section{Problem Based Learning (PBL)}

Problem-based Learning (PBL) is a learning model that presents a contextual problem that stimulates students to active learning. Students work in teams to solve real-world problems. The PBL model is a useful model for teaching high-level thinking processes (analysis, synthesis, evaluation, creativity). This learning helps students to process information in their minds and 
prepare their knowledge about the social world and its surroundings. This PBL is suitable for developing basic and complex knowledge [1]. PBL is a learning model that starts from a problem; students learn a concept and principle while solving problems. PBL is better at increasing critical thinking skills, practicing independent learning, and solving problems in reallife situations. According to [6], effective learning is learning related to how students think to overcome an obstacle.

[7] and [8], explain that the PBL has the characteristics as follows: (1) The problem focused, as students learn based on problems, (2) it is student centered, namely the student-centered learning process, (3) self-directed learning, that is, students control their own learning process even though it is still in the corridor of predetermined learning goals, (4) self-reflective, i.e. students make reflections on the learning process and outcomes.

\section{Cooperative Learning}

The cooperative learning model was developed to achieve at least three essential learning objectives, namely academic learning outcomes, acceptance of diversity, and the development of social skills. Slavin (1997) in [1] states that cooperative learning is a learning model in which students work actively in groups that have different capabilities. Collaborative learning refers to a learning model that encourages students to work together in small groups and help one another in education. Cooperative learning as a set of teaching strategies used by teachers for the students helps each other to learn something. There are four types of collaborative learning models proposed by Arends (2001) in [1], namely; (1) Student Teams Achievement Division (STAD), (2) Group Investigation, (3) Jigsaw, and (4) Structural Approach that consists of Think-Pair-Share (TPS), and Numbered-Head-Together (NHT).

In STAD learning model, there are several steps in conducting the model; they are: learning in teams, where students work in their teams guided by learning activity sheets to complete lecture material, giving tests, and giving rewards for the team that achieves the highest score. While in group investigation learning model, there are several steps suc as: choosing particular sub-topic within a common problem that is commonly decided by the lecturers, planning the learning procedure and specific objectives that are suitable to the sub-topics decided, and implementing the plan that they have set in the second stage. Lecturer closely observes the progress of each group and provides an assistance when needed, (4) the students analyze and evaluate the information obtained in the third stage and plan how the information is summarized and presented in the class, (5) some or all of the groups present the investigation's results, with the aim that all students know the topic. This presentation is coordinated by the lecturer, (6) the evaluation can be individual or group.

The steps of the Jigsaw implementation can be read as follows: (1) the lecturers divide a class into groups, with each group consisting of 4-6 students, (2) after the students discussed in the expert group and the original group, hereinafter each group do a presentation, (3) lecturers give a quiz to the students individually, (4) the lecturers give awards to the group through an achievement score. The material should naturally be divided into several parts of the learning material.

The steps of TPS are (1) thinking: the lecturers provide questions or issues related to the material to be studied and ask students to think about the question, or the problem is independently for some time, (2) pairing: the lecturers ask the students to work in pair. Interaction at this stage is expected to share the answers. The lecturers give 4-5 minutes for working in pairs, (3) sharing: the lecturer asks the students who work in pairs to share about what they have discussed classically. These steps are effectively done by rolling in pairs until about a quarter of the groups to report. 
The NHT steps are (1) numbering: the lecturers divide students into groups of 3-5 people, and each member is given numbers 1 to $5,(2)$ asking questions: lecturers ask a question to students. This question can be in the form of question or directive sentences, (3) thinking together: the students unites their opinion on the answer to the question and assure members in their team to know the answer, (4) answers: the lecturer calls the student with a certain number, then the student will answer the lecturer questions classically [9].

\section{Inquiry Learning}

Inquiry learning is based on Piaget's cognitive theory. According to Piaget, there are three stages in learning, namely assimilation, accommodation, and equilibration. Assimilation is the process of adjusting/ integrating/ integrating the new knowledge/ new information with cognitive structures that are already in the minds of students. Accommodation is the process of cognitive structure appropriateness of students with new knowledge. Equilibration is the process of mental balancing/ adjustment after it has been done in the process of assimilation or accommodation. Equilibration can be said well if people are able to organize information in good order, clear, and logical. However, equilibration can be said less; if it stores less information, people tend to think complicated, illogical, and convoluted [9].

The success of the learning process is influenced by the optimization of students in using their logic in linking fundamental knowledge with their experiences during the learning process. Fundamental knowledge has a vital role in inquiry learning methods.

[1] argues that for implementing the inquiry model, a teacher must actively think and behave that facilitates the students to be able to make the identification of what will be learned. The lecturer helps students to be active in making questions, determining strategies for gathering information, and processing information. This approach requires lecturers who are creative in structuring learning and working with good plans. When students learn, students already have a clear target. This active approach gives a pretty good challenge for the lecturer or students. Lecturer and students become engaged and learners at the same time; even in certain situations, lecturers and students will learn about the same thing. The inquiry learning model will make students more aware of the process of inquiry and learn about scientific procedures and work directly. Learning approach with inquiry model consists of five stages, namely: (1) Stage of presenting problems or exposing students to situations that trigger student curiosity, (2) data collection and verification, (3) stages of experimentation, (4) stages of organizing data and formulating explanation, (5) the stage of conducting an analysis of the inquiry process.

[10] explains that there are several steps in the application of inquiry learning, namely: (1) exploration (activities by exploring various information relating to the concept to be studied), (2) identification of problems (carrying out problem identification activities based on information obtained by students), (3) submission of hypotheses (students formulate hypotheses). Hypothesis is a temporary answer to the problem that has been formulated by students, (4) data collection and analysis (students begin activities to collect data and information from various sources to test/ answer hypotheses), (5) reflection is the inquiry step in which students conduct activities to reflect back on the process learning [9].

\subsection{Research-Based Learning Strategies}

According to Griffith University (2008) in [11], several strategies in integrating learning and research empirically developed include:

a. Enrich teaching materials with the results of lecturer research.

b. Using the research findings of the study and track the history of the development found. 
c. Enrich teaching activities with research issues.

d. Teach research methodology material in the learning process.

e. Enrich the learning process with research activities on a small scale.

f. Enhancing learner by involving students in research.

g. Enriching the learning process by encouraging students to feel part of the research culture in the faculty/ department.

h. Enriching the learning process with values that must be possessed by researchers.

\section{Research Method}

The type of research used is Research and Development (R\&D), which consists of three steps, namely: the preparatory stage, the development stage, and the results reporting stage. The development phase has produced teaching material in educational psychology courses with research-based learning models and arrived at the stage of implementing the models in the classroom. The next development stage is to test the effectiveness of research-based learning models by looking at student learning outcomes and student responses to textbooks and the implementation of books in class. The population of this study is students of the English Language Study Program, students of the Indonesian Language and Literature Education Study Program, and the second-semester students of the Sciences Education Study Program of Faculty of Education and Teachers' Training. The data collection techniques used were tests, questionnaires, and observations. The instruments used include the syllabus, draft textbooks, and pretest and posttest questions. The data analysis technique used is one group pretestposttestst design.

\section{Results and Discussion}

The results of the research into the effectiveness of the research-based model in Educational Psychology Learning subject are as follows:

\section{Implementation of Learning with the Research-based Learning Model}

The draft textbook that was developed consists of ten (10) chapters and is presented in the following table:

Table 1. Contents Books Instructional Course Educational Psychology

\begin{tabular}{|c|c|c|}
\hline No & Chapter & Research-Based Learning Model (BBR) is used \\
\hline 1 & Psikologi Pendidikan & $\begin{array}{l}\text { The strategy "Teaches research methodology material in } \\
\text { the learning process" with the method " Problem Based } \\
\text { Learning (PBL) " }\end{array}$ \\
\hline 2 & Gejala Jiwa & $\begin{array}{l}\text { The strategy "Teaching material research methodology in } \\
\text { the learning process" with the technique of " Guided } \\
\text { Inquiry Learning " }\end{array}$ \\
\hline 3 & Perbedaan Individual & $\begin{array}{l}\text { The strategy "Enriches the learning process with values } \\
\text { that must be possessed by lecturers and students as } \\
\text { researchers" with the " POGIL (Process Oriented Guided } \\
\text { Inquiry Learning) method " }\end{array}$ \\
\hline 4 & Belajar & $\begin{array}{l}\text { The strategy is "Enriching the learning process with } \\
\text { values that must be possessed by lecturers and students as }\end{array}$ \\
\hline
\end{tabular}




\begin{tabular}{|c|c|c|}
\hline & & $\begin{array}{l}\text { researchers" with the method "Cooperative Type STAD } \\
\text { (Student Teams Achievement Division)" }\end{array}$ \\
\hline 5 & $\begin{array}{l}\text { Teori Belajar Behavioristik dan } \\
\text { Penerapannya dalam } \\
\text { Pembelajaran }\end{array}$ & $\begin{array}{l}\text { The strategy "Using research findings and tracing the } \\
\text { history of the development of research" with the method } \\
\text { of "Jigsaw Cooperative Type" }\end{array}$ \\
\hline 6 & $\begin{array}{l}\text { Teori Belajar Kognitif dan } \\
\text { Penerapannya dalam } \\
\text { Pembelajaran }\end{array}$ & $\begin{array}{l}\text { The strategy is "Using research findings and tracking the } \\
\text { history of the development of research" with the method } \\
\text { of "Cooperative Jigsaw Type and NHT (Numbered Head } \\
\text { Together)" }\end{array}$ \\
\hline 7 & $\begin{array}{l}\text { Teori Belajar Humanistik dan } \\
\text { Penerapannya dalam } \\
\text { Pembelajaran }\end{array}$ & $\begin{array}{l}\text { The strategy is "Using research findings and tracking the } \\
\text { history of the development of research" with the method } \\
\text { of "Cooperative Type NHT (Numbered Head Together)" }\end{array}$ \\
\hline 8 & $\begin{array}{l}\text { Teori Belajar Kognitif dan } \\
\text { Penerapannya dalam } \\
\text { Pembelajaran }\end{array}$ & $\begin{array}{l}\text { The strategy "Using research findings and tracing the } \\
\text { history of the development of research" with the method } \\
\text { of "Jigsaw Cooperative Type" }\end{array}$ \\
\hline 9 & $\begin{array}{l}\text { Teori Belajar Konstruktivistik dan } \\
\text { Penerapannya dalam } \\
\text { Pembelajaran }\end{array}$ & $\begin{array}{l}\text { The strategy is "Using research findings and tracking the } \\
\text { history of the development of research" with the method } \\
\text { of "Cooperative Think Pair Share (TPS)" }\end{array}$ \\
\hline 10 & Evaluasi Hasi Belajar & $\begin{array}{l}\text { The strategy is "Enriching the learning process with } \\
\text { values that must be possessed by lecturers and students as } \\
\text { researchers" with the method "Cooperative Type of } \\
\text { Group Investigation" }\end{array}$ \\
\hline
\end{tabular}

The syntax of implementing BBR learning model generally includes the stages of orientation, exploration, concept formation, application, and closure. The explanation of each step is as follows.

At the orientation stage, the lecturer has prepared students physically and psychologically, with the preparation of a psychology textbook draft. Each chapter of the draft textbooks has decided: basic competence, indicators, learning scenario, learning materials, and exercises. To test the sign and basic skill, the lecturers provide a pretest. At the exploration stage, the lecturer provides motivation and guidance to students to conduct observational activities in groups so that students can form and master the concepts. Students determine problems, make hypotheses, analyze problems, and organize ideas in flipcharts. In the concept formation stage, students present in front of the class and communicate the results of observations or group discussions in the form of reports written on flipchart paper. The group leader allows students to express their opinions and ask questions related to the material being discussed. The group leader answers questions and summarizes the results of the discussion and presentation. In the application phase, the lecturer advises students to (1) practice a lot to do the questions in each chapter of the draft textbook, (2) apply the psychology theory of learning in real life. At the closure stage, the lecturer reinforces the concept, reviews, together with the student, concludes the learning outcomes, provides a posttest, and conducts reflections and follows up on the material. The implementation of Research-based Learning in learning activity can be read as follows:

Table 2. Average Implementation of Research-Based Learning Model

\begin{tabular}{llcccc}
\hline & & \multicolumn{3}{c}{ Percentage } & Average \\
\cline { 3 - 5 } No & \multirow{2}{*}{ BBR Syntax } & Science & Study Program & \\
& & 97 & 100 & PBSI & \\
1 & Orientation & 70 & 100 & 86 & 94 \\
2 & Exploration & & 63 & 78 \\
\hline
\end{tabular}




\begin{tabular}{llcccc}
\hline 3 & Concept Formation & 89 & 100 & 91 & 93 \\
4 & Application & 65 & 89 & 86 & 80 \\
5 & Closure & 100 & 100 & 100 & 100 \\
& Average & $\mathbf{8 4 . 2}$ & $\mathbf{9 7 . 8}$ & $\mathbf{8 5 . 2}$ & $\mathbf{8 9}$ \\
\hline
\end{tabular}

Table 1 shows that the level of feasibility of research-based learning models obtained an average of $89 \%$ of learning accomplishment. It means, overall, the implementation of the Research-based Learning model is in accordance with the syllabus and draft textbooks that have been prepared and have been done in good categories. Learning with the Research-based Learning model has a positive influence on increasing the ability to think at a high level, especially analysis, evaluation, conclusions, and self-regulation. Through Research-based Learning activities in the stages of exploration, concept formation, and application, students are trained to develop the ability of analysis, evaluation, and conclusions [4].

\section{Students Learning Outcomes}

Finding out the effectiveness of the Research-based Learning model in the study of Educational Psychology Learning subject in three study programs, the post-test scores were compared with the pre-test scores. They were analyzed with quasi-experimental techniques, namely one-group pretest-posttest design. Student learning outcomes were analyzed using a range of cognitive competency values in accordance with the indicators that have been formulated in the draft textbook as follows.

Table 3. Summary Analysis of One Group Pre-test-Post-test Design

\begin{tabular}{|c|c|c|c|c|c|c|c|c|}
\hline No & $\begin{array}{l}\text { Study Program } \\
\text { (Class Group) }\end{array}$ & $\begin{array}{l}\text { Mean } \\
\text { Pretest }\end{array}$ & $\begin{array}{c}\text { Mean } \\
\text { Post- } \\
\text { test }\end{array}$ & $\mathrm{db}$ & t-count & $\begin{array}{l}\text { t-table } \\
(1 \%)\end{array}$ & $\begin{array}{c}\text { Test } \\
\text { Decision }\end{array}$ & $\begin{array}{c}\text { Average } \\
\text { difference }\end{array}$ \\
\hline 1 & $\begin{array}{l}\text { English Language } \\
\text { Education (Class } \\
\text { Group 1) } \\
\text { Chapter 6. Teori } \\
\text { Belajar Kognitif } \\
\text { Chapter 7. Teori } \\
\text { Belajar Humanistik } \\
\text { Chapter 8. Teori } \\
\text { Belajar Sibernetik } \\
\text { Chapter 9. Teori } \\
\text { Belajar } \\
\text { Konstruktivistic } \\
\text { Chapter 10. } \\
\text { Evaluasi Belajar }\end{array}$ & $\begin{array}{l}56 \\
65\end{array}$ & $\begin{array}{l}98 \\
89\end{array}$ & $\begin{array}{l}32 \\
35\end{array}$ & $\begin{array}{l}18.6133 \\
11.6968 \\
7.9234 \\
11.1213 \\
9.5465\end{array}$ & $\begin{array}{l}2.704 \\
2.704 \\
2.704 \\
2.750 \\
2.704\end{array}$ & $\begin{array}{l}\text { Ho rejected } \\
\text { Ho rejected } \\
\text { Ho refused } \\
\text { Ho refused } \\
\text { Ho refused }\end{array}$ & $\begin{array}{l}\text { Significant } \\
\text { Significant } \\
\text { Significant } \\
\text { Significant } \\
\text { Significant }\end{array}$ \\
\hline 2 & $\begin{array}{l}\text { Indonesian } \\
\text { Language } \\
\text { Education } \\
\text { Chapter 6. Teori } \\
\text { Belajar Kognitif } \\
\text { Chapter 7. Teori } \\
\text { Belajar Humanistik } \\
\text { Chapter 8. Teori } \\
\text { Belajar Sibernetik } \\
\end{array}$ & $\begin{array}{r}39 \\
58 \\
59 \\
\end{array}$ & $\begin{array}{l}98 \\
90 \\
\end{array}$ & 33 & $\begin{array}{c}15.0600 \\
16.3308 \\
12.3704 \\
8.1849 \\
\end{array}$ & $\begin{array}{r}2.704 \\
2.750 \\
2.750 \\
2.763 \\
\end{array}$ & $\begin{array}{l}\text { Ho refused } \\
\text { Ho rejected } \\
\text { Ho refused } \\
\text { Ho refused }\end{array}$ & $\begin{array}{l}\text { Significant } \\
\text { Significant } \\
\text { Significant } \\
\text { Significant }\end{array}$ \\
\hline
\end{tabular}




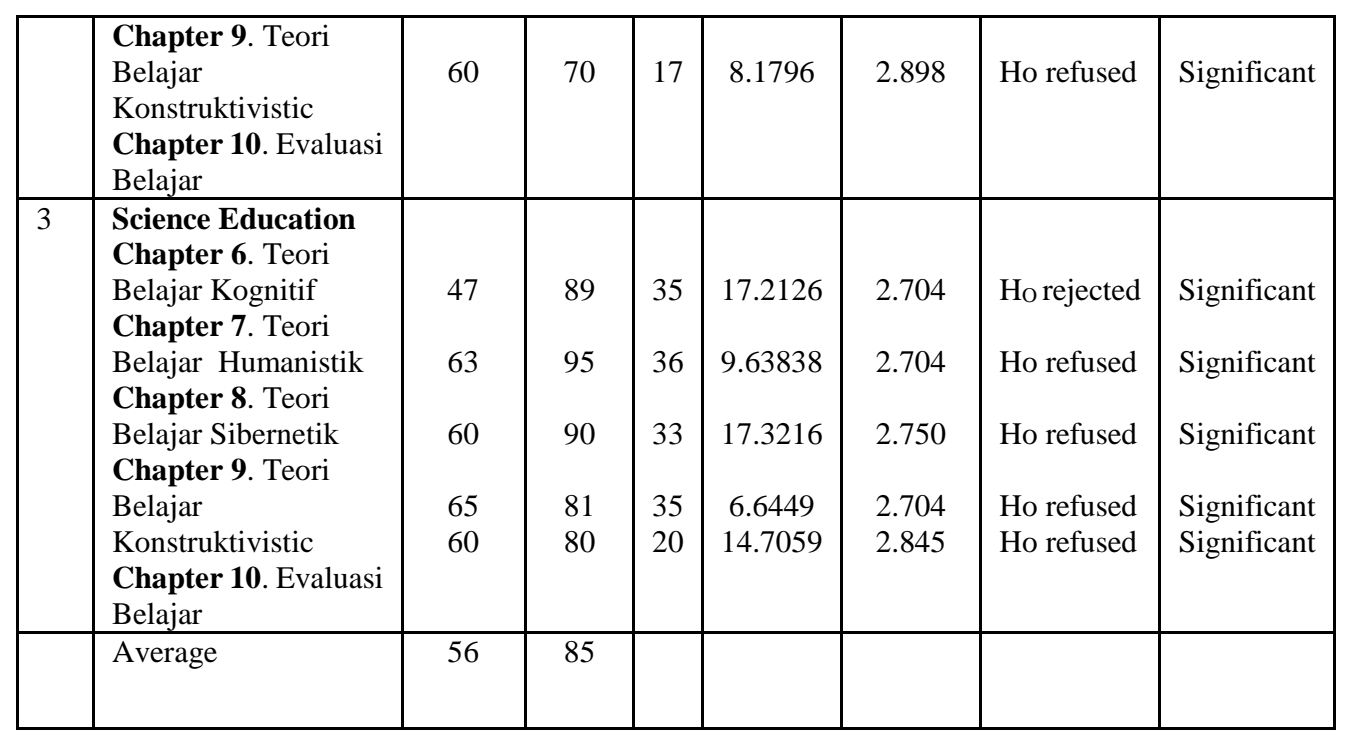

Finding out the effectiveness of the Research-based Learning model in learning Educational Psychology Learning, the results show that the Research-based Learning model can effectively improve learning outcomes. This is proved by the existence of a significant average difference between learning outcomes before and after learning by using the Research-based Learning model in the classroom. The results of the research analysis show that the average before learning is 56, and the standard after learning is 85, meaning there is an increase of 29.

\section{Conclusions}

The results of this study state that the development of teaching material "Educational Psychology with Research-Based Learning Models" already includes: the event of a draft of Educational Psychology Learning textbooks with research-based learning models. The development of the draft textbook consists of 10 chapters accompanied by essential competencies, indicators, learning syntax with selected research-based learning strategies and methods, and a description of the material and exercises.

The development of the draft textbook course " Educational Psychology" by using a research-based learning model, is considered feasible by experts to be used in learning. It is proven that $70 \%$ states the book is suitable to be used with revisions and $30 \%$ without corrections. From the results of the validation from peers it is found that: (a) $100 \%$ of teaching materials are in accordance with basic competencies and indicators; (b) $85 \%$ of teaching materials according to the needs of students; (c) $90 \%$ of the teaching material is accurate, (d) $100 \%$ of the teaching material compiled is up to date; (e) $95 \%$ of the teaching material has clear information; (f) $95 \%$ of the presentation of appropriate teaching materials; (g) $90 \%$ of the presentation techniques are complete and good; (h) $75 \%$ had fulfilled the research-based learning method model, (i) $67 \%$ states that the textbook design was good and complete; (j) $100 \%$ of the validator stated that the textbook give advantages for lecturers and students, and (k) $30 \%$ of the validator stated that the "draft of Educational Psychology textbooks using research-based 
learning models" is feasible to be used without revisions and $70 \%$ provide opinions that it is feasible to be used with revisions.

The results of the students' response stated that $76.84 \%$ stated that the book was suitable to be used and was effective for use. While the increase in learning outcomes obtained by 29 or increased from an average of 56 to an average of 85 .

\section{References}

[1] Sudarmin, "Pembelajaran Aktif dan Implementasinya dalam Konteks Kurikulum Tahun 2013," in Seminar Nasional ALFA VI di Universitas Widya Dharma, Klaten, 2016.

[2] d. Slameto, "Pengembangan Model Pembelajaran Berbasis Riset Untuk Meningkatkan Keterampilan Berpikir Aras Tinggi. https://www.geogle.co.id/url?sa=t\&rct=j\&q=\&esrc=s\&source=web\&cd=3...," 2016.

[3] BSNP, "Paradigma Pendidikan Nasional. Abad XXI," Jakarta, 2010.

[4] M. T. d. Hanib, "Penerapan Pembelajaran POGIL untuk Meningkatkan Kemampuan Berpikir Kritis dan Karakter Siswa Kelas X.," http://journal.um.ac.id/index.php/jptpp/article/view/8381, 2017.

[5] L. G. \&. S. M. J. Snyder, "Teaching critical thinking and problem-solving skills.," The Delta Pi Epsilon Journal, L, vol. 2, p. 90-99, 2008.

[6] e. a. Chen, "Prompting in web Based Environment: Supporting Self Monitoring and Problem Solving Skills in College Student.," Journal of Educational Computing Research., vol. 38, no. 2, pp. 115-137, 2008.

[7] W. e. a. Hung, "Problem Based Learning," The Interdiciplinary Journal of Problem Based Learning, vol. 1, no. 38, pp. 235-266, 2008.

[8] A. e. a. Kolmos, Problem Based Learning, Selahattin Kuru: TREE Isik University, 2007.

[9] S. Haryati, Buku Ajar Belajar Pembelajaran Berbasis Pembelajaran Kooperatif, Yogyakarta: Graha Cendekia, 2017.

[10] S. Wardoyo, Pembelajaran Berbasis Riset, Jakarta: Akademia Permata, 2013.

[11] Widayati, Pedoman Umum Pembelajaran Berbasis Riset (PUPBR), Yogyakarta: UGM, 2010. 